Abant Tıp Dergisi

Derleme / Cilt 9 Sayı 3 YII 2020
Abant Medical Journal

Review / Volume 9 Issue 3 Year 2020

\title{
Hormon Reseptör Pozitif, İnsan Epidermal Büyüme Faktörü Reseptör2 Negatif Metastatik Meme Kanserli Hastalarda Tedavi Seçenekleri
}

\section{Treatment Options in Hormone Receptor Positive, Human Epidermal Growth Factor Receptor2 Negative Metastatic Breast Cancer Patients}

\author{
Ümmügül Üyetürk \\ Bolu Abant Izzet Baysal Üniversitesi, Tıp Fakültesi, Tıbbi Onkoloji Bilim Dalı, Türkiye
}

\section{Öz}

Meme kanserleri(MK) kadınlarda en sık görülen ve ikinci sıklıkta ölüme neden olan kanserlerdir. Hastaların \%3-8 metastatik evrede tanı almakta, \%40'unda da takipte metastaz gelişmektedir. Bu hastaların tedavisinde visseral kriz veya endokrin tedavi direnci yoksa östrojen hormonunun reseptörlere bağlanmasını engelleyici ya da östrojen üretimini azaltıcı endokrin tedavi önerilmektedir. Çünkü metastatik MK hastalarda çok istisnai vakalar dışında kür sağlanamamaktadır. Hastalarda semptom kontrolü, hastalık progresyonunun geciktirilmesi ve hastalık progresyonuna bağlı ciddi komplikasyonlardan önlenmesi, yaşam kalitesin devam ettirebilmesi ve sonuçta sağkalım süresinin uzatılmaya çalışılmalıdır. Hastaların pre/perimenapozal veya menapozal dönemde olup olmadıkları tedavi seçiminde önemlidir. Pre/perimenapozal dönemde selektif östrojen reseptör modülatörleri (Tamoksifen), progresyon olduğunda over ablasyonu/ supresyon ile birlikte postmenapozal dönemdeki tedaviler kullanılabilir. Postmenapozal dönemde ise Tamoksifen, Aromataz inhibitörleri: nonsteroidal (Letrozol veya Anastrozol) ve steroidal (Exemestan), östrojen reseptör down regülatörü (Fulvestrant) seçenekler arasındadır. Ayrıca endokrin tedavilere direnç gelişimi durumunda etkinliğinin artırılması amacıyla siklin bağımlı kinaz 4/6 inhibitörleri (Palbociclib, Ribociclib, Abemaciclib), ve mTOR inhibitörü (Everolimus), fosfotidil inositol 3 kinaz inhibitörü (Buparlisib) gibi hedefe yönelik moleküllerle kombinasyon tedavileri uygulanabilir. Ayrıca hedefe yönelik tedavilerin endokrin tedavilerle kombinasyonları etkinliğini artırmaktadır.

Anahtar Kelimeler: Metastatik Meme Kanseri, Endokrin Tedavi, Siklin Bağımlı Kinaz 4/6 İnhibitörleri, mTOR inhibitörü, Fosfotidil İnositol 3 Kinaz İnhibitörleri

\section{Abstract}

Breast cancers (BC) are the most common cancers in women and the second most common cause of cancer death.3-8\% of the patients are diagnosed at metastatic stage, and $40 \%$ of them develop metastasis at follow-up. If there is no visceral crisis or endocrine treatment resistance in the treatment of these patients, endocrine therapy which prevents the binding of estrogen hormone to receptors or reduces estrogen production is recommended. Because cure cannot be achieved in metastatic BC patients except in very exceptional cases. In patients, symptom control, delaying disease progression and preventing serious complications related to disease progression, maintaining the quality of life and consequently survival should be tried to be extended. Whether patients are in pre/perimenopausal or menopausal period is important in the treatment selection. Selective estrogen receptor modulators (Tamoxifen) are used in the pre / perimenopausal period. When there is progression to tamoxifen, the treatments used in the postmenopausal period can be used together with ovarian ablation/ suppression. In the postmenopausal period, Tamoxifen, Aromatase inhibitors: nonsteroidal (Letrozole or Anastrozole) and steroidal (Exemestan), estrogen receptor down regulator (Fulvestrant) are among the options. In addition, combination therapy with targeted molecules such as cyclin dependent kinase 4/6 inhibitors (Palbociclib, Ribociclib, Abemaciclib), and mTOR inhibitor (Everolimus), phosphotidyl inositol 3 kinase inhibitor (Buparlisib) can be applied in order to increase effectiveness in case of resistance to endocrine treatments. Also, combinations of targeted therapies with endocrine treatments increase their effectiveness.

Keywords: Metastatic Breast Cancer, Endocrine Treatment, Cyclin Dependent Kinase 4/6 Inhibitors, mTOR inhibitors, Phosphatidyl Inositol 3 Kinase Inhibitors 


\section{GíRiş}

Çin Meme kanserleri (MK) tüm dünyada kadınlarda deri kanserleri hariç olmak üzere en sık görülen ve akciğer kanserlerinden sonra ikinci sırada ölüme neden olan kanserlerdir (1). Bu kanserlerin yaklaşık \%60-70 inde hormon reseptör (HR) yani östrojen reseptör(ER) ve/veya progesteron reseptör(PR) pozitiftir (2). Tümör nükleuslarının \%1-100 pozitif boyanması östrojen reseptör pozitif olarak yorumlanmalıdır. Fakat \%1-10 arası boyanmada endokrin tedavinin faydası ile ilgili bilgiler sınırlıdır. Progesteron testi için de benzer prensipler geçerlidir (3).

MK'lerinin \%3-8'i tanı anında metastatik evrededir. Erken evre tanı konulan hastaların da takip süresi içinde de \%40'ında metastaz gelişmektedir (4). HR pozitif, insan epidermal büyüme faktörü reseptör (HER) 2 negatif metastatik MK hastalarda visseral hastalık olsa bile visseral kriz veya endokrin tedavi direnci kanıtı olmayan durumlarda östrojen hormonunun reseptörlere bağlanmasını engelleyici ya da östrojen üretimini azaltıcı endokrin tedavi önerilmektedir (5). Çünkü metastatik MK hastalarda çok istisnai vakalar dışında kür sağlanamamaktadır. Hastalarda semptom kontrolü, hastalık progresyonunun geciktirilmesi ve hastalık progresyonuna bağlı ciddi komplikasyonlardan önlenmesi, yaşam kalitesin devam ettirebilmesi ve sonuçta sağkalım süresinin uzatılmaya çalışılmalıdır (6).

Tedavi seçiminde hastanın yaşı, menapoz durumu, performansı ve ek hastalıkları, tümör yükü (metastazların sayısı ve yeri), hastalığın ilerleme hızı, önceki uygulanan tedaviler ve yan etkileri, sosyo-ekonomik ve psikolojik faktörler, ülkedeki ödeme koşulları göz önünde bulundurulmalıdır $(5,6)$.

\section{Neden Endokrin Tedavi Tercih Edilmelidir?}

Metastatik MK hastalarda endokrin tedavi tercih edilmelidir. Çünkü kemoterapiye göre yan etkileri belirgin daha azdır ve uzun süreli yanıt sağlayabilir. Ayrıca kemoterapi ile arasında sağkalım farkı bulunmamaktadır. Endokrin direnci veya visseral kriz olmadığı sürece (visseral organ metastazı durumlarında bile) kemoterapiye tercih edilebilir $(7,8)$.

\section{Endokrin Direnci Nedir?}

Endokrin direnci primer ve sekonder olmak üzere ikiye ayrılmaktadır. Primer endokrin direnci MK hastada adjuvan hormonal tedavinin ilk 2 yılı içinde hastalıkta nüks olması veya metastatik evrede başlanan 1. sıra endokrin tedavinin ilk 6 ayı içinde hastalıkta progresyon görülmesidir. Sekonder endokrin direnci ise adjuvan endokrin tedavinin 2 yılından sonra veya adjuvan tedavi bitiminden ilk 12 ay içinde nüks olması veya metastatik durumda 1.sıra tedaviyle 6 ay veya sonrasında hastalıkta progresyon olmasıdır (5).Endokrin tedaviye direnç de novo, tedavi sırasında kazanılmış, ER kaybına bağlı östrojen bağımlılığının kaybı, ER pozitifliği devam etmesine rağmen östrojen bağımlılığının kaybı,t ümör hala östrojen bağımlı olmasına rağmen spesifik bir tedaviye direnç şeklinde karşımıza çıkabilir. Bunun nedeni ESR1 mutasyonları, büyüme faktörü reseptörlerinin sinyal yolakları, pP13K/AKT/mTOR ve RAF/MEK/ERK yolaklarının aktivasyonu, hücre siklus kontrol noktalarındaki değişikliklerdir (6).

\section{Visseral Kriz Nedir?}

Hastalarda visseral metastazlara bağlı olarak klinik semptomlar ve laboratuar değerleriyle birlikte, ciddi organ disfonksiyonunu ve hastalıkta hızlı progresyon olmasıdır (7).

Metastatik MK hastaların menapozal durumlarına göre endokrin tedavi seçimine dikkat edilmelidir.

\section{Pre/perimanapozal Dönemdeki Metastatik Meme Kanserli Hastalarda Endokrin Tedavi Seçenekleri}

Pre/perimenapozal dönemdeki hastalarda 
endokrin tedavi olarak selektif östrojen reseptör modülatörü (Tamoksifen) kullanılabilir. Eğer tamoksifeni adjuvan tedavide almış ve nüks gelişmişse ovaryan ablasyon/ süpresyon ile birlikte postmenapozal kadınlardaki endokrin tedavi seçenekleri düşünülmelidir.

\section{Selektif Östrojen Reseptör Modülatörü}

Selektif östrojen reseptör modülatörü olan Tamoksifen 1970'lerden beri kullanılmaktadır. Tamoksifen östrojen reseptörüne bağlanır ve östrojenin reseptöre bağlanmasını engelleyerek östrojenik etkinin ortaya çıkmasını engeller. Hem pre/perimenapozal hem de postmenapozal kadınlarda kullanılabilir. Olası yan etkileri menapoz belirtileri şeklindedir. Sıcak basması, terleme, duygu durum değişiklikleri, vajinal kuruluk veya akıntı, adet kesilmesi, halsizlik; nadiren de vücutta pıhtı oluşu ve endometrium kanseri gibi yan etkiler görülebilir (8).

\section{Over Ablasyonu/ Süpresyonu Nasıl Yapılır?}

Kadınlarda östrojenin ana kaynağı premenapozal dönemde overlerdir. Overlerin fonksiyonlarını ortadan kaldırmak için ooferektomi, overlere radyasyonla ve medikal olarak luteinizing hormone-releasing hormone (LHRH) anologları kullanılabilinir. Ooferektomi, irreversibldir. Dolaşımdaki östrojeni azaltır ama kalıcı fertiliteye neden olur ve hastaneye yatış gereklidir. Overlere radyasyon uygulaması da irreversibldir. Ooferektomi ile sonuçları eşit etkilidir. Medikal olarak over fonksiyonlarının supresyonu ilk iki işlemden farklı olarak reversibldir, LHRH analogları kullanılarak yapılabilir $(9,10)$.

\section{Luteinizing Hormon Releasing Hormon Anologları}

Bu ilaçlardan goserelinin aylık ve 3 aylık formları karşılaştırıldığında güvenlik profili, etki profili, over supresyonu arasında fark bulunamamıştır. Yine farklı LHRH analogları (goserelin, leuprolid, buserelin, triptorelin) arasında fark yoktur (9).
Postmanapozal Dönemdeki Metastatik Meme Kanserli Hastalarda Endokrin Tedavi Seçenekleri

Bu dönemdeki hastalarda Tamoksifen, Aromataz İnhibitörleri: Nonsteroidal (Letrozol veya Anastrozol) ve Steroidal (Exemestan), Östrojen Reseptör Down Regülatörü (Fulvestrant) seçenekler arasındadır.

\section{Aromataz İnhibitörleri}

Aromataz enzimi overde östrojen üretiminin kesilmesinden sonra, östrojenin tek kaynağı olan adrenal androjenlerin östrojen substratlarına, sitokrom P-450 bağımlı dönüşümünden sorumlu enzimdir. Aromataz inhibitörleri, androstenedionun estrona ve testesteronun estradiole çevrilmesini inhibe ederler (10). Steroidal inaktivatör (1. kuşak bulunmamaktadır, 2. kuşak Formestan, 3. kuşak Eksemestan) ve nonsteroidal inhibitörler (1.kuşak Aminoglutetimid, 2.kuşak Fadrazol, Rogletimid, 3.kuşak Letrozol, Anastrozol, Vorozol) olmak üzere ayrılmaktadır(11).

Postmenapozal metastatik MK hastalarda aromataz inhibitörlerinden letrozol ile yapılan bir çalışmada median genel sağkalımda (GSK) letrozol grubunda tamoksifene göre hafifçe bir uzama tespit edilmiştir (34 aya karşı 30 ay) (12). Anastrozol ile yapılan başka bir çalışmada anastrozolün tamoksifen kadar etkili olduğu ve anastrozol grubunda tamoksifen grubundan daha az tromboembolik olay (\% 4.8 karşı $\% 7.3$ ) ve vajinal kanama (\% 1.2 karşı \% 2.4) görüldügü bulunmuştur (13). Bu çalışmalara istinaden postmenapozal hastalarda aromatoz inhibitörlerini tamoksifene tercih edilerek ilk sırada başlama görüşü hakim olmuştur.

\section{Selektif Östrojen Reseptör Down Regülatörü}

Fulvestrant birinci generasyon selektif östrojen reseptör down regülatörüdür. Östrojen reseptör agonistik etki göstermez (14). Amerikan Gıda ve İlaç Dairesi (FDA) onayını 2002 yılında tamoksifen 
veya aromataz inhibitörlerine progresyon sonrası $250 \mathrm{mg}$ olarak almıştır. Fakat $250 \mathrm{mg}$ ile $500 \mathrm{mg}$ karşılaştırıldığı faz 3, CONFiRM çalışmasında toksisiteyi artırmadan $500 \mathrm{mg}$ dozunun progresyonsuz sağkalım (PSK) süresinde uzamaya neden olduğu bulunmuştur. Pre/perimenapozal kadınlarda LHRH analogları ile birlikte kullanılmalıdır (15).

Fulvestrant ile Anastrozolün etkinliğinin karşılaştırıldığı faz 2, FIRST çalışmasında, cevap oranları Fulvestrant \%36.0 ile Anastrozol \%35.5 olarak benzer bulunmuştur. Ama Fulvestrant kullananlarda median progresyon zamanına ulaşılamazken, anastrozol grubunda median PSK 12.5 ay olarak bulunmuştur (16).Bu konu ile ilgili faz 3, FALCON çalışmasına, 20 ülke ve 462 metastatik MK hasta katılımıştır. Fulvestrant (500 $\mathrm{mg}$ ) ve Anastrozolün etkinliği karşılaştırılmıştır. Median PSK Fulvestrant grubunda 16.6 ayken, anastrozol grubunda 13.8 ay olarak bulunmuştur. Birinci basamak endokrin tedavide Fulvestrant, Aromataz İnhibitörlerine üstün bulunmuştur (17).

\section{Endokrin Tedaviye Direnç Durumunda Ne Yapılmalıdır?}

HR pozitif, HER 2 negatif Metastatik MK tek başına uygulanan endokrin tedavilere cevap oranı 1 yıldan sonra azaldığı ve tedaviye direncin geliştiği görülmüştür. Bu durumda diğer endokrin seçenekleri tercih edilebilir. Ayrıca endokrin direnci ortadan kaldırarak, yanıt süresini uzatabilmek için hedefe yönelik Siklin Bağımlı Kinaz(CDK) inhibitörleri, mTOR İnhibitörleri ve Fosfotidil İnositol 3 Kinaz İnhibitörleri ile kombinasyonlar tedavide kullanılabilir.

\section{Siklin Bağımlı Kinaz 4/6 İnhibitörleri}

Büyüme faktörleri, onkojenler, siklinler ve CDK hücre bölünmesi ve çoğalmasına katkı sağlarken, tümör süpresör genler (p53, Rb), CDK inhibitörleri hücre bölünmesi ve çoğalmasını durdurmaktadır. CDK4 ve siklin D1 tümör süpresör gen retinoblastomun fosforilasyon ve inhibisyonundan sorumludur. Retinoblastom fosforile olduğu zaman hücre siklusunda G1 fazından S fazına geçilir, Deoksiribo Nükleik Asit (DNA) replikasyonu ve mitoz için hazırlık başlar. CDK4/6 inhibitörleri retinoblastom tümör süpresör geninin defosforilasyonu ile spesifik olarak hücre siklusunda G1 den S fazına geçişi bloke eder (18).

Günümüzde Palbociclib, Ribociclib, Abemaciclib CDK 4/6 inhibitörü olarak HR pozitif, HER2 pozitif, postmenapozal, metastatik MK hastalarda Aromatoz İnhibitörleri veya Fulvestrant ile kombine kullanılmaktadır.

\section{Palbociclib}

Palbociclib bir CDK 4/6 inhibitörüdür. Şubat 2015 FDA onayı PALOMA 1 çalışmasıyla almıştır. Endikasyon onayını HR pozitif, HER2 negatif ileri veya metastatik MK hastalarda, postmenapozal dönemde başlangıç endokrin tedavisinde aromataz inhibitörü ile kombine olarak ve endokrin tedaviye progresyon görülen hastalarda fulvestrant ile kombine olarak almıştır.

Faz 2, PALOMA 1 çalışmasında daha önce herhangi bir tedavi almamış, postmenapozal, ER pozitif ve HER2 negatif, ileri evre MK 165 hasta Letrozol (2.5 mg/gün) grubu ve Letrozol + Palbociclib (125 mg/gün 3 hafta ilaç, 1 hafta ara) grubuna randomize edilmiştir. Ayrıca hastalar potansiyel biyobelirteçlere bakılmadan randomize edilen 66 hasta ve CD1 amplifikasyonu pozitif veya p16 kaybı olan veya her ikisi de pozitif olan hastalar (99 hasta) olmak üzere iki gruba daha randomize edilmiştir. Tüm grubun ortak analizinde, ortanca 29.6 aylık izlem sonucunda, çalışmanın birincil sonlanım noktası olan PSK letrozol grubunda 10.2 ayken Letrozol+Palbociclib grubunda 20.2 ay bulunmuştur. Bu yarar, potansiyel biyo belirteçlerden bağımsız olarak tüm grupta görülmüştür. Alt grup analizlerinde Palbociclib yararının yaş, metastaz bölgesi ve daha önce alınmış olan sistemik tedavilerden etkilenmediği saptanmıştır. İkincil sonlanım noktası olan GSK 
Letrozol grubunda 33.3 ayken Letrozol+Palbociclib grubunda 37.5 ay olarak bulunarak istatistiksel fark görülmemiştir. Letrozol+Palbociclib kolunda hastaların $\% 54$ 'ünde grade $3 / 4 \quad$ nötropeni görülmüştür Nötropenik ateş veya nötropeniye bağlı enfeksiyon görülmemiştir. Ayrıca grade $3 / 4$ yorgunluk \%4 vs \%1 daha fazla tespit edilmiştir (19).

Çift kör, prospektif, randomize, plasebo kontrollü PALOMA 2 çalışmasına postmenapozal, HR pozitif, HER2 negatif ileri evre/ metastatik MK, daha önce metastatik hastalık için tedavi almamış ve aromataz inhibitörü direnci olmayan 666 hasta (2/1 randomizasyon) alınmıştır. Hastalar Letrozol+Palbociclib ve Letrozol kollarına randomize edilmişlerdir. Ortanca PSK Letrozol+Palbociclib grubunda 24.8 ay ve Letrozol grubunda 14.5ay; genel yanıt oranı sırasıyla $\% 42.1$ ve \%34.7 olarak bulunmuştur. Alt grup analizlerinde yarar tüm gruplarda mevcut olduğu görülmüştür. Biyo belirteçlere göre bakıldığında median PSK, Rb negatif ve $\mathrm{p} 16$ negatif olan alt gruplarda da Letrozol+Palbociclib grubunda Letrozol grubundan daha uzun tespit edimiştir. En sık görülen yan etki myelotoksisite olup PALOMA1 çalışmasıyla benzer bulunmuştur (20).

Palbociclibin etkinliği; endokrin tedaviyle progrese olmuş, pre/perimenapozal (hastaların \%21) ve postmenapozal 521 metastatik MK hastaların alındığı faz 3 , randomize, çift kör, plasebo kontrollü bir çalışmada Fulvestrant (ilk 3 doz 14 gün arayla $500 \mathrm{mg}$, daha sonra 28 günde bir $500 \mathrm{mg}$ ) ile kombine edilerek etkinliği ve güvenilirliği değerlendirilmiştir. Hasta pre/perimenapozal dönemdeyse goserelin 4 hafta fulvestrant öncesinde uygulanmıştır. Pre/perimenapozal grupta median PSK Palbociclib+Fulvestrant grubunda 9.5 aya karşın Plasebo+Fulvestrant grubunda 5.6 ay, postmenapozal grupta median PSK Palbociclib+Fulvestrant grubunda 9.9 aya karşın Plasebo+Fulvestrant grubunda 3.9 ay bulunmuştur (21).

\section{Ribociclib}

Ribociclib endikasyon onayını Mart 2017'de MONALEESA 2 çalışmasıyla HR pozitif, HER2 negatif, ileri veya metastatik evredeki MK hastalarda, postmenapozal dönemde başlangıç endokrin tedavisinde aromataz inhibitörü ile kombine olarak, endokrin tedaviye progresyon görülen hastalarda fulvestrant ile kombine olarak almıştır.

Randomize, faz 3, 668 postmenapozal, HR pozitif, HER2 negatif daha önce ileri evre hastalık için tedavi almamış nüks veya metastatik $\mathrm{MK}$ hastanın alındığı MONALEESA 2 çalışmasında hastalar Ribociclib $(600$ mg/gün 3 hafta ilaç, 1 hafta ara)+Letrozol (334) ile Plasebo+Letrozol (334) gruplarına randomize edilmiştir.18 ay takip sonrası PSK oranı Ribociclib+Letrozol grubunda $\% 63$, Letrozol grubunda \%42.2 ve median PSK, Ribociclib+Letrozol grubunda ulaşllamazken, Letrozol grubunda 14.7 ay olarak bulunmuştur (22).

Faz 3,484 postmenapozal, daha öncesinde endokrin tedavi naif veya tedavi almış olan metastatik MK hastaların alındığı MONALEESA 3 çalışmasında hastalar Ribociclib +Fulvestrant grubu ve Plasebo+Fulvestrant grubu olmak üzere randomize edilmiştir. Median PSK, Ribociclib+Fulvestrant grubunda 20.5 aya karşın Plasebo+Fulvestrant grubunda 12.8 ay bulunmuştur (23).

Faz 3, 30 ülke, 188 merkezin katıldığı, MONALEESA 7 çalışmasında pre/perimenapozal HR pozitif, HER2 negatif ileri evre MK hastalar Ribociclib+ Tamoksifen, ve Ribociclib+ nonsteroidal aromatoz inhibitörü (Anastrozol veya Letrozol) gruplarına randomize edilmiştir. Hastaların hepsi goserelin kullanmıştır. Tüm hastalar birlikte değerlendirildiğinde median PSK, Ribociclib grubunda 23.8 ay $(\% 95 \mathrm{Cl} 19.2-$ ulaşılamadı) plasebo grubunda 13.0 ay (11.016.4) olarak bulunmuştur. Tamoksifen+Ribociclib grubunda (177) 22.1 ayken Tamoksifen+ Plasebo grubunda 11.0 ay ve nonsteroidal aromatoz 
inhibitörü +Ribociclib grubunda 27.5 ayken (\%95 Cl 19.1-ulaşılmadı) ve nonsteroidal aromatoz inhibitörü +plasebo grubunda $13 \cdot 8$ ay (12.6-17.4) olarak bulunmuştur. Pre/perimenapozal hasta grubunda da HR pozitif, HER 2 negatif ileri evre MK hastalarda, yönetilebilir güvenlik profili ile Ribociclib+Endokrin tedavi (tamoksifen, anastrozol ve letrozol), sadece endokrin tedaviye göre PSK iyileşme sağlamaktadır sonucuna ulaşılmıştır (24).

\section{Abemaciclib}

Abemaciclib endikasyon onayını Şubat 2017' de MONARCH 2 çalışmasıyla HR pozitif, HER2 negatif ileri evre MK hastalarda postmenapozal dönemde başlangıç endokrin tedavisi olarak aromataz inhibitörleri ile kombine olarak ya da endokrin tedaviden sonra progrese olan hastalarda fulvestrant ile kombine olarak kullanılır şeklinde almıştır.

Faz 3, MONARCH 3 çalışmasında, postmenapozal, HR pozitif ve HER 2 negatif, daha önce sistemik tedavi almamış, ileri evre MK hastalar Abemaciclib (150 mg 2×1) + nonsteroidal aromatoz inhibitörü (Anastrozol veya Letrozol) (493 hasta) ve Plasebo+ nonsteroidal aromatoz inhibitörü (Anastrozol veya Letrozol) (165 hasta) gruplarına randomize edilmiştir. Abemaciclib + nonsteroidal aromatoz inhibitörü kolunda median PSK ulaşılamazken, plasebo+ nonsteroidal aromatoz inhibitörü kolunda 14.7 ay olarak bulunmuştur. Objektif yanıt oranı Abemaciclib kolunda \%59, plasebo kolunda \%44 olduğu görülmüştür (25).

Faz 3, MONARCH 2 çalışmasında HR pozitif, HER 2 negatif, neoadjuvan veya adjuvan endokrin tedaviyle ilerlemiş ileri evre MK hastalar Abemaciclib (150 mg 2x1) + Fulvestrant (446 hasta) ve Plasebo+Fulvestrant (223 hasta) gruplarına randomize edilmiştir. Median PSK, Abemaciclib+Fulvestrant grubunda 16.4 ayken, Plasebo+Fulvestrant kolunda 9.3 ay bulunmuştur (26).
Günümüzde Palbociclib, Ribociclib ve Abemaciclib için yapılan çalışmaları değerlendiren bir meta analizde CDK4/6 inhibitörlerinin özellikle HR pozitif, HER 2 negatif ileri evre MK hastalarda endokrin tedaviyle kombine olarak PSK önemli iyileşme edildiği, ilaçların birbirine herhangi bir üstünlüğü olmadığı, eşit etkinlikte olduğu, grade 3-4 yan etki profilinin de benzer olduğu bulunmuştur. Bununla birlikte Palbociclibte Abemaciclib ile kıyaslandığında ishal riskinin düşük olduğu, yine Palbociclibin Ribociclib ile kıyaslandığında uzamış QTc riskinde azalma mevcuttur. CCNE1 geni Palbociclibe direnç için potansiyel bir biyomarker olabileceği sonucuna varılmıştır (27).

\section{Mammalian Target of Rapamycin İnhibitörleri}

HR pozitif hastalıkta sıklıkta endokrin tedaviye direnç gelişmektedir. Direnç mekanizmalarından biri mammalian target of rapamycin(mTOR) sinyal iletim yolu aktive olmasıdır. Bu durumda Mammalian Target of Rapamycin (mTOR) inhibisyonu yapan Everolimus kullanılmaktadır (28).

Faz 3, BOLERO-2 çalışmasında postmenapozal, HR pozitif ileri evre MK nonsteroidal aromatoz inhibitörü sonrası progresyon görülen, $\% 59$ 'unda visseral hastalık mevcut olan 724 hasta, 2/1 oranında (Everolimus (10 mg/gün) +Eksemestane (25 mg/gün) ve Placebo +Eksemestane gruplarına randomize edilmiştir. Median PSK Everolimus +Eksemestan grubunda 10.6 ayken, Plasebo +Eksemestan grubunda 4.1 ay bulunmuştur. Everolimus grubunda halsizlik, stomatit, hiperglisemi, pnömonitis en sık görülen yan etkiler olmuştur, Bu çalışmayla metastatik MK hastalarda nonsteroidal aromatoz inhibitörü sonrası progresyon görülen hastalarda Eksemestan+Everolimus ile dual blokajın (steroidal inaktivatör ve mTOR), güvenilir ve klinik olarak etkin olduğu bulunmuştur (29).

Faz 2, Gineco çalışmasında postmenapozal, 
nonsteroidal aromatoz inhibitörü kullanımı sonrasında direnç gelişen, HR pozitif, HER2 negatif, ileri evre MK hastalar Tamoksifen+ Everolimus ( 54 hasta) ve Tamoksifen+Plasebo (57 hasta) gruplarına randomize edilmiştir. Altı aylık klinik fayda oranı Tamoksifen+Everolimus grubunda \%61 iken, Tamoksifen grubunda \%42, median PSK Tamoksifen grubunda 4.5 ayken Tamoksifen+Everolimus grubunda 8.6 ay bulunmuş ve kombinasyon grubundaki hastalarda \%46 progresyon riskinde azalma tespit edilmiştir en önemli yan etkiler Tamoksifen+ Everolimus grubunda yorgunluk, stomatit, raş, anoreksi ve diyare olarak rapor edilmiştir (30).

\section{Fosfotidil İnositol 3 Kinaz İnhibitörleri}

PI3K enzimleri hücre çoğalması, hücre ölümü, hücre hareketi ve hücre invazyonu gibi süreçlerde rol alan hücresel sinyal iletim yolağının elemanlarıdır. Bu enzimler lipid kinazlar olarak fonksiyon gösterir. Tümör baskılayıcı özellikte olan ve PI3K sinyal iletiminin negatif düzenleyicisi PTEN molekülü işlevsiz hale gelince bu sistem hücrede sürekli aktif hale gelir. Pan PI3K inhibitörleri Buparlisib, Pictilisib ve İsoformspesifik PI3K inhibitörleri Alpelisib, Taselisib mevcuttur (31).

\section{Buparlisib}

Faz 3, 29 ülke ve 267 merkezin katıldığı, BELLE 2 çalışmasında aromataz inhibitör kullanımı sonrası progresyon görülen, kemoterapi almış, postmenapozal, HR pozitif, HER 2 negatif ileri evre MK hastalar Buparlisib (100 mg / gün) + Fulvestrant ve Plasebo+ Fulvestrant gruplarına 1:1randomize edilmiştir. Buparlisib+Fulvestrant kollarında median PSK 6.9 ayken, Plasebo+Fulvestrant kolunda 5 ay olarak bulunmuştur. BELLE 2 çalışmasında endokrin dirençli hastalarda PI3K inhibisyonu ile endokrin tedavi kombinasyonunun efektif ve güvenilir olduğu sonucuna ulaşmışlardır (31).

\section{SONUÇ}

HR pozitif, HER2 negatif, metastatik MK hastalarda visseral kriz veya endokrin tedavi direnci yoksa östrojen hormonunun reseptörlere bağlanmasını engelleyici ya da östrojen üretimini azaltıcı endokrin tedavi önemlidir. Selektif östrojen reseptör modülatörü tamoksifen hem pre /perimenapozal dönemde hem de postmenapozal dönemde kullanılabilir. Post menapozal dönemde aromatoz inhibitörleri (Anastrozol, Letrozol ve Eksemestane) ve selektif östrojen dowm regülatörü fulvestrant kullanılabilir. Bu tedavi seçenekleri pre/perimenapozal hastada over ablasayonu veya LHRH analogları over supresyonu ile kullanılmalıdır. Endokrin tedavi direncinde veya etkinliği artırmak için CDK 4/6 inhibitörleri (Palbociclib, Ribociclib, Abemaciclib), ve mTOR inhibitörü (Everolimus), PI3K (Buparlisib) gibi hedefe yönelik ilaçlarla kombinasyon tedavileri uygulanabilir. Hastalarda progresyonunu engelleyecek, sağkalım süresini uzatırken yaşam kalitesini bozmayacak ve yan etki profili kolay yönetebilir endokrin ve hedefe yönelik tedavilerle ilgili yeni çalışmalara ihtiyaç vardır ve bu konu ile ilgili çalışmalar devam etmektedir.

Bilgilendirilmiş Onam: Katılımcılardan sözlü onam alınmıştır.

Çıkar Çatışması: Yazarlar çıkar çatışması beyan etmemişlerdir.

Finansal Destek: Yazarlar finansal destek beyan etmemişlerdir.

\section{KAYNAKÇA}

1. DeSantis CE, Ma J, Gaudet MM, Newman LA, Miller KD, Goding Sauer A, et al. Breast cancer statistics, 2019. CA: a cancer journal for clinicians. 2019 Nov;69(6):438-51. PubMed PMID: 31577379. Epub 2019/10/03. eng.

2. Nadji M, Gomez-Fernandez C, Ganjei-Azar P, Morales AR. Immunohistochemistry of estrogen and progesterone receptors reconsidered: experience with 5,993 breast cancers. American journal of clinical pathology. 2005 Jan;123(1):21-7. PubMed PMID: 15762276. Epub 2005/03/15. eng.

3. Allison $\mathrm{KH}, \mathrm{Hammond} \mathrm{MEH}$, Dowsett M, McKernin SE, Carey LA, Fitzgibbons PL, et al. Estrogen and Progesterone Receptor Testing in Breast Cancer: American Society of Clinical Oncology/College of American Pathologists Guideline Update. Archives of 
pathology \& laboratory medicine. 2020 Jan 13. PubMed PMID: 31928354. Epub 2020/01/14. eng.

4. Jemal A, Bray F, Center MM, Ferlay J, Ward E, Forman D. Global cancer statistics. CA: a cancer journal for clinicians. 2011 Mar-Apr;61(2):69-90. PubMed PMID: 21296855. Epub 2011/02/08. eng.

5. Giuliano $M$, Schettini $F$, Rognoni $C$, Milani M, Jerusalem $\mathrm{G}$, Bachelot $\mathrm{T}$, et al. Endocrine treatment versus chemotherapy in postmenopausal women with hormone receptor-positive, HER2-negative, metastatic breast cancer: a systematic review and network metaanalysis. The Lancet Oncology. 2019 Oct;20(10):13609. PubMed PMID: 31494037. Epub 2019/09/09. eng.

6. Luqmani YA, Alam-Eldin N. Overcoming Resistance to Endocrine Therapy in Breast Cancer: New Approaches to a Nagging Problem.Med Princ Pract. 2016 Jul; 25(Suppl 2): 28-40. PubMed PMID: 26849149.Epub 2016/02/05.eng.

7. Harb WA. Management of patients with hormone receptor-positive breast cancer with visceral disease: challenges and treatment options. Cancer management and research. 2015; 7:37-46. PubMed PMID: 25653556. Pubmed Central PMCID: PMC4310719. Epub 2015/02/06. eng.

8. Shagufta, Ahmad I. Tamoxifen a pioneering drug: An update on the therapeutic potential of tamoxifen derivatives. European journal of medicinal chemistry. 2018 Jan 1; 143:515-31. PubMed PMID: 29207335. Epub 2017/12/06. eng.

9. Noguchi S, Kim HJ, Jesena A, Parmar V, Sato N, Wang $\mathrm{HC}$, et al. Phase 3, open-label, randomized study comparing 3-monthly with monthly goserelin in premenopausal women with estrogen receptor-positive advanced breast cancer. Breast cancer (Tokyo, Japan). 2016 Sep;23(5):771-9. PubMed PMID: 26350351. Pubmed Central PMCID: PMC4999470. Epub 2015/09/10. eng.

10. Balam FH, Ahmadi ZS, Ghorbani A. Inhibitory effect of chrysin on estrogen biosynthesis by suppression of enzyme aromatase (CYP19): A systematic review. Heliyon. 2020 Mar;6(3): e03557. PubMed PMID: 32181408. Pubmed Central PMCID: PMC7063143. Epub 2020/03/18. eng.

11. Smith IE, Dowsett M. Aromatase inhibitors in breast cancer. The New England journal of medicine. 2003 Jun 12;348(24):2431-42. PubMed PMID: 12802030. Epub 2003/06/13. eng.

12. 12. Irish W, Sherrill B, Cole B, Gard C, Glendenning GA, Mouridsen $H$. Quality-adjusted survival in a crossover trial of letrozole versus tamoxifen in postmenopausal women with advanced breast cancer. Annals of oncology: official journal of the European Society for Medical Oncology. 2005 Sep;16(9):1458-62. PubMed PMID: 15946978. Epub 2005/06/11. eng.

13. Mouridsen $H$, Chaudri-Ross HA. Efficacy of first-line letrozole versus tamoxifen as a function of age in postmenopausal women with advanced breast cancer. The oncologist. 2004;9(5):497-506. PubMed PMID: 15477634. Epub 2004/10/13. eng.

14. Nathan MR, Schmid P. A Review of Fulvestrant in Breast Cancer. Oncology and therapy. 2017;5(1):17-29. PubMed PMID: 28680952. Pubmed Central PMCID: PMC5488136. Epub 2017/07/07. eng.

15. Di Leo A, Jerusalem G, Petruzelka L, Torres R, Bondarenko IN, Khasanov $\mathrm{R}$, et al. Results of the CONFIRM phase III trial comparing fulvestrant $250 \mathrm{mg}$ with fulvestrant $500 \mathrm{mg}$ in postmenopausal women with estrogen receptor-positive advanced breast cancer. Journal of clinical oncology: official journal of the American Society of Clinical Oncology. 2010 Oct 20;28(30):4594-600. PubMed PMID: 20855825. Epub 2010/09/22. eng.

16. Robertson JF, Llombart-Cussac A, Rolski J, Feltl D, Dewar J, Macpherson E, et al. Activity of fulvestrant $500 \mathrm{mg}$ versus anastrozole $1 \mathrm{mg}$ as first-line treatment for advanced breast cancer: results from the FIRST study. Journal of clinical oncology: official journal of the American Society of Clinical Oncology. 2009 Sep 20;27(27):4530-5. PubMed PMID: 19704066. Epub 2009/08/26. eng.

17. Robertson JFR, Bondarenko IM, Trishkina E, Dvorkin M, Panasci L, Manikhas A, et al. Fulvestrant 500 mg versus anastrozole $1 \mathrm{mg}$ for hormone receptor-positive advanced breast cancer (FALCON): an international, randomised, double-blind, phase 3 trial. Lancet (London, England). 2016 Dec 17;388(10063):29973005. PubMed PMID: 27908454. Epub 2016/12/03. eng.

18. Malumbres M. Cyclin-dependent kinases. Genome biology. 2014;15(6):122. PubMed PMID: 25180339. Pubmed Central PMCID: PMC4097832. Epub 2014/09/03. eng.

19. Finn RS, Crown JP, Lang I, Boer K, Bondarenko IM, Kulyk SO, et al. The cyclin-dependent kinase 4/6 inhibitor palbociclib in combination with letrozole versus letrozole alone as first-line treatment of oestrogen receptor-positive, HER2-negative, advanced breast cancer (PALOMA-1/TRIO-18): a randomised phase 2 study. The Lancet Oncology. 2015 Jan;16(1):25-35. PubMed PMID: 25524798. Epub 2014/12/20. eng.

20. Rugo HS, Finn RS, Gelmon K, Joy AA, Harbeck N, Castrellon $A$, et al. Progression-free Survival Outcome Is Independent of Objective Response in Patients With Estrogen Receptor-positive, Human Epidermal Growth Factor Receptor 2-negative Advanced Breast Cancer Treated With Palbociclib Plus Letrozole Compared With Letrozole: Analysis From PALOMA-2. Clinical breast cancer. 2019 Sep 5. PubMed PMID: 31836434. Epub 2019/12/15. eng.

21. Cristofanilli M, Turner NC, Bondarenko I, Ro J, Im SA, 
Masuda N, et al. Fulvestrant plus palbociclib versus fulvestrant plus placebo for treatment of hormonereceptor-positive, HER2-negative metastatic breast cancer that progressed on previous endocrine therapy (PALOMA-3): final analysis of the multicentre, doubleblind, phase 3 randomised controlled trial. The Lancet Oncology. 2016 Apr;17(4):425-39. PubMed PMID: 26947331. Epub 2016/03/08. eng.

22. Ribociclib as First-Line Therapy for HR-Positive, Advanced Breast Cancer. The New England journal of medicine. 2018 Dec 27;379(26):2582. PubMed PMID: 30586508. Epub 2018/12/27. eng.

23. Slamon DJ, Neven $P$, Chia $S$, Fasching PA, De Laurentiis $\mathrm{M}$, Im SA, et al. Phase III Randomized Study of Ribociclib and Fulvestrant in Hormone Receptor-Positive, Human Epidermal Growth Factor Receptor 2-Negative Advanced Breast Cancer: MONALEESA-3. Journal of clinical oncology: official journal of the American Society of Clinical Oncology. 2018 Aug 20;36(24):246572. PubMed PMID: 29860922. Epub 2018/06/05. eng.

24. Tripathy D, Im SA, Colleoni M, Franke F, Bardia A, Harbeck N, et al. Ribociclib plus endocrine therapy for premenopausal women with hormone-receptorpositive, advanced breast cancer (MONALEESA-7): a randomised phase 3 trial. The Lancet Oncology. 2018 Jul;19(7):904-15. PubMed PMID: 29804902. Epub 2018/05/29. eng.

25. Goetz MP, Toi M, Campone M, Sohn J, Paluch-Shimon S, Huober J, et al. MONARCH 3: Abemaciclib As Initial Therapy for Advanced Breast Cancer. Journal of clinical oncology: official journal of the American Society of Clinical Oncology. 2017 Nov 10;35(32):3638-46. PubMed PMID: 28968163. Epub 2017/10/03. eng.

26. Sledge GW, Jr., Toi M, Neven P, Sohn J, Inoue K, Pivot $X$, et al. MONARCH 2: Abemaciclib in Combination With Fulvestrant in Women With HR+/HER2- Advanced Breast Cancer Who Had Progressed While Receiving Endocrine Therapy. Journal of clinical oncology: official journal of the American Society of Clinical Oncology. 2017 Sep 1;35(25):2875-84. PubMed PMID: 28580882. Epub 2017/06/06. eng.

27. Sobhani N, D'Angelo A, Pittacolo M, Roviello G, Miccoli A, Corona SP, et al. Updates on the CDK4/6 Inhibitory Strategy and Combinations in Breast Cancer. Cells. 2019 Apr 6;8(4). PubMed PMID: 30959874. Pubmed Central PMCID: PMC6523967. Epub 2019/04/10. eng.

28. Hasskarl J. Everolimus. Recent results in cancer research Fortschritte der Krebsforschung Progres dans les recherches sur le cancer. 2018; 211:101-23. PubMed PMID: 30069763. Epub 2018/08/03. eng.

29. Baselga J, Campone M, Piccart M, Burris HA, 3rd, Rugo HS, Sahmoud T, et al. Everolimus in postmenopausal hormone-receptor-positive advanced breast cancer. The New England journal of medicine. 2012 Feb 9;366(6):520-9. PubMed PMID: 22149876. Pubmed
Central PMCID: PMC5705195. Epub 2011/12/14. eng.

30. Bachelot T, Bourgier C, Cropet C, Ray-Coquard I, Ferrero JM, Freyer G, et al. Randomized phase II trial of everolimus in combination with tamoxifen in patients with hormone receptor-positive, human epidermal growth factor receptor 2-negative metastatic breast cancer with prior exposure to aromatase inhibitors: a GINECO study. Journal of clinical oncology: official journal of the American Society of Clinical Oncology. 2012 Aug 1;30(22):2718-24. PubMed PMID: 22565002. Epub 2012/05/09. eng.

31. Campone $\mathrm{M}$, Im SA, Iwata $\mathrm{H}$, Clemons $\mathrm{M}$, Ito $\mathrm{Y}$, Awada $A$, et al. Buparlisib plus fulvestrant versus placebo plus fulvestrant for postmenopausal, hormone receptorpositive, human epidermal growth factor receptor 2negative, advanced breast cancer: Overall survival results from BELLE-2. European journal of cancer (Oxford, England: 1990). 2018 Nov; 103:147-54. PubMed PMID: 30241001. Epub 2018/09/22. eng. 